\title{
Conodonts and ostracodes from the late Tournaisian bathyal sequence of the Polar Urals
}

\author{
Andrey V. Zhuravlev*, Dmitriy B.Sobolev \\ N.P.Yushkin Institute of Geology Komi SC UrB RAS, 54 Pervomayskaya St., Syktyvkar, Russia \\ * corresponding author: avzhuravlev@geo.komisc.ru
}

Received: $5^{\text {th }}$ March, 2018

Accepted: $19^{\text {th }}$ March, 2018

\begin{abstract}
Early Carboniferous (late Tournaisian) conodonts, recovered from siliceous shales and silicites of the NyanVorga Formation within the Lemva tectonic belt of the Polar Urals (Russia), include the biostratigraphically important taxa Siphonodella lanei, Gnathodus typicus, Dollymae hassi, and Scaliognathus anchoralis, marking the following conodont zones of the upper Tournaisian: crenulata, typicus, and anchoralis. Associated species include representatives of genera Siphonodella, Polygnathus, Pseudopolygnathus, Dollymae, Gnathodus, Kladognathus, and Idioprioniodus. These conodont faunas provide the first biostratigraphically constrained correlations between bathyal deposits of the Lemva Allochthone in the Polar Urals and the "standard" conodont zonation. Ostracodes found in the silicite of the typicus Zone are represented by Sagittibythere? sp. and Tricornina (Bohemia) sp. The ostracodes are reported from the bathyal deposits of Urals for a first time. The traces of the global Mid-Aikuanian Event are recognized in the upper part of the Tournaisian bathyal succession. This event led to turnover in conodont associations and is followed by increasing in conodont diversity.
\end{abstract}

Key words: Carboniferous, conodonts, ostracodes, bathyal, Polar Urals

\section{Introduction}

The late Tournaisian was a time of dramatic changes in the climate and ocean circulation caused by the transition from the greenhouse climate to the icehouse one (Saltzman et al. 2004; Yao et al. 2015). This transition, named the Mid-Aikuanian Event (Ji 1987), probably caused the extinction among conodonts at the Siphonodella isosticha Zone followed by gradual recovery in the typicus - anchoralis zones (Ziegler and Lane 1987; Kalvoda 1994). The recovery fauna comprises Gnathodus, Eotaphrus, some Peudopolygnathus, Bactrognathus, Dollymae, Doliognathus, Staurognathus, and Scaliognathus. Most representatives of these genera dwelt the basin environment (Sandberg and Gutschick 1984; Dreesen, et al. 1986; Kalvoda 1994) and widespread over the Laurussia shelfs.
Despite the importance of conodonts for biostratigraphic purposes in the upper Tournaisian deep-water successions, very little has been reported on the conodont faunas in the NE Laurussia (recent Polar Urals and Pai-Khoi) (Zhuravlev 2003; Zhuravlev and Gerasimova 2016a). Data on ostracodes in the bathyal deposits of this region are absent.This article is aimed to characterize of the conodont and ostracode associations came from the bathyal Polar Urals section.

\section{Geological settings}

During the Tournaisian time, the Northern Urals basin was located in the palaeotropical realm in the northwestern part of the Uralian Strait (Fig. 1). The study area is located in the Lemva tectonic belt comprising bathyal deposits of the middle Palaeozoic age overthrusting the shelf 

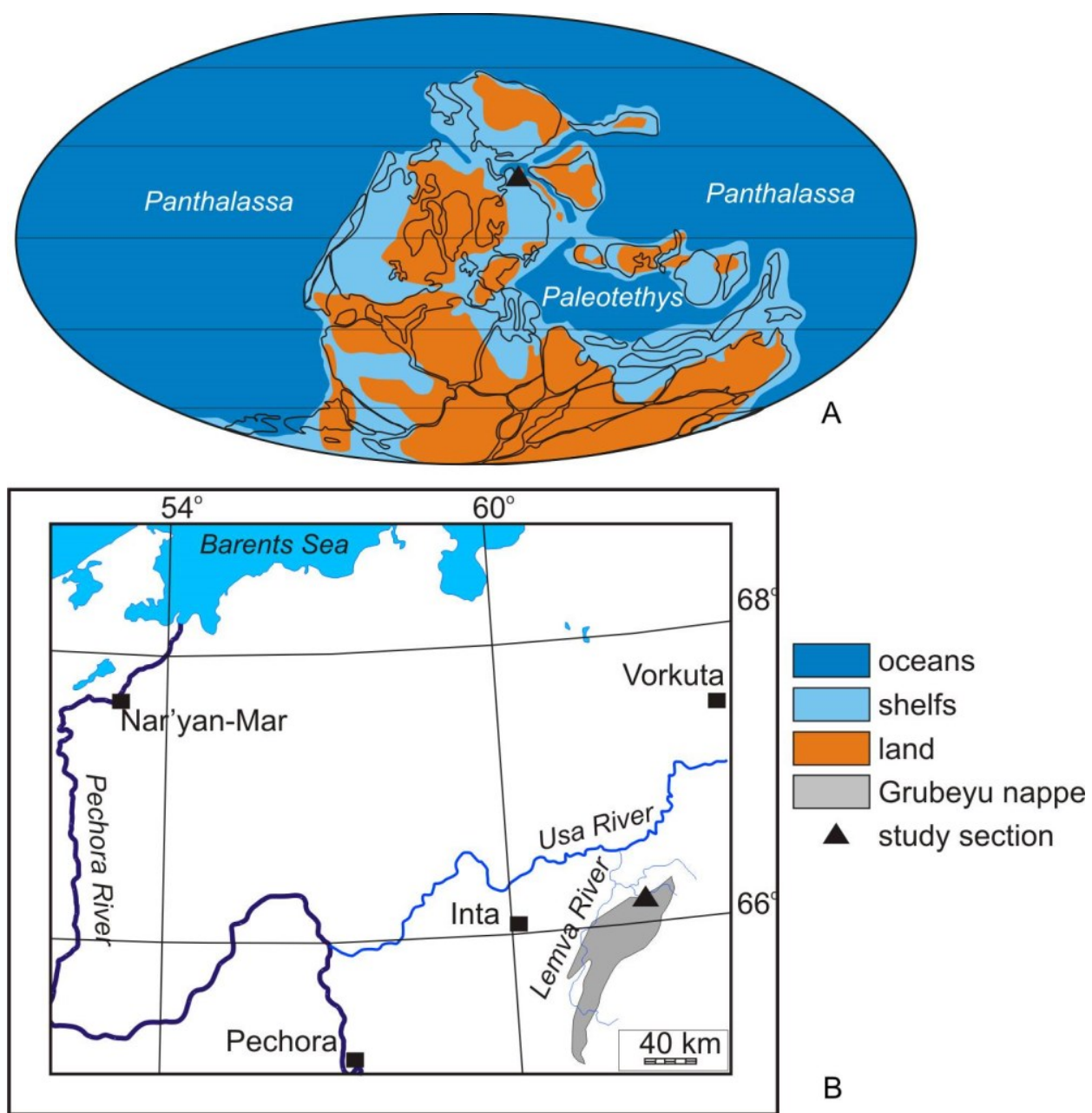

Fig.1. Locality maps. A - Palaeogeographic position of the study section; palaeogeographic map is based on Scotese (2016). B - Recent location of the section.

deposits (e.g. Yudin 1994; Puchkov 2002, 2010). The Lemva tectonic belt is composed of a number of the overthrust nappes. The section under consideration (Lemva River basin, NyanVorga Creek, N 6557'30.64" E 62 3'6.21", Fig. 1) is located in the Grubeyu nappe (Yudin 1994). The Upper Devonian - Lower Carboniferous of the Grubeyu neppe are represented by the silicites, shales, and allochtonous detritic limestones forming Bouma cyclites. The deposits, named as the Nayn-Vorga Formation, are extremely faulted and folded, and compose small nappes. So it is difficult to find continuous sections of the Formation (Ovnatanova et al. 2017).

The study section exposed on the right bank of the Nyan-Vorga Creek comprises the upper Famennian - Tournaisian part of the Nyan-
Vorga Formation (Zhuravlev 2003). Just the upper (Tournaisian) part of the section was studied in details (Fig. 2). This work is based on the 24 samples of clayey silicites, shales, and carbonates collected from the upper part (about $20 \mathrm{~m}$ thick) of the Nyan-Vorga Formation (Fig. 2).

\section{Material and methods}

The silicite and shale samples were studied with X-ray microtomography (Zhuravlev and Gerasimova 2016b) and SEM. Most of conodont elements and ostracode shells are entirely solved due to decomposition of sulfides and forming sulphuric acid in the deposits. Thus, just moulds possessing external form of the fossils are preserved. Rare ostracode shells 


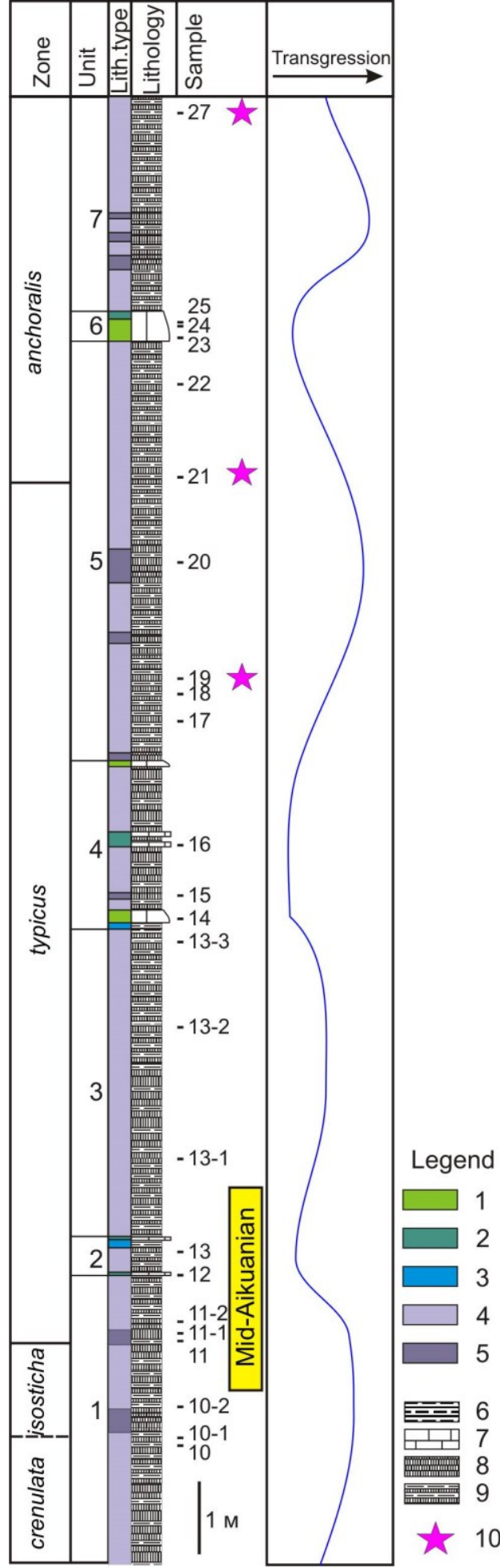

Fig.2. Log of the studied section of the Nyan-Vorga Formation. Legend: 1 - bio- and lithoclastic limestones; 2 - micritic clayey limestones; 3 laminated shales; 4 - alternation of clayey silicites and cherty shales; 5 - silicites with radiolaries and spicules; 6 - shale; 7 - limestone; 8 - silicite; 9 - thin alternation of shales and clayey silicites; 10 - ash layers. are represented by poorly preserved partly pyritized moulds.This mode of preservation causes study of the samples by X-ray microtomography, following the procedure described by Zhuravlev and Gerasimova (2016b). About $1.2 \mathrm{~cm}^{3}$ of silicites and shales from 3 samples $(11 ; 18 ; 21)$ were studied by microtomograph SkyScan1272 with spatial resolution of $2 \mu \mathrm{m}$.

Additionally the disrupted bed plane assemblages of conodonts were studied on the bedding surfaces of cherty shales. These samples were studied with SEM after carbon coating (Fig. 3).

Carbonate layers contain unsolved conodont elements possessing conodont alteration index $\mathrm{CAI}=5$. Processing of limestone samples followed the standard procedure documented by Harris and Sweet (1989) (dissolution of limestone in 10\% buffered acetic acid). The residues were washed through a sieve of $70 \mu \mathrm{m}$, dried, and conodont elements were picked up.

All figured specimens are deposited in the Geological Museum of Institute of geology Komi SC UrB RAS, Syktyvkar, Russia (collections \# 687 and \#689).

\section{Results}

The studied part of the Nyan-Vorga Formation can be divided lithologically into seven units (Fig. 2):

1. Thin alternation of dark-gray clayey silicites and cherty shales. Bed of dark silicite yielded radiolaries in the middle part of the unit. The unit is $4 \mathrm{~m}$ thick.

2. Thin alternation of dark-gray clayey silicites yielded radiolaries and cherty shales interbedded by thin laminated carbonate layers. The unit is $0.5 \mathrm{~m}$ thick.

3. Thin alternation of dark-gray clayey silicites and cherty shales. $4.2 \mathrm{~m}$ thick.

4. Thin alternation of dark-gray clayey silicites and cherty shales interbedded by thin 
carbonate layers interpreted as calciturbidites. $2.3 \mathrm{~m}$ thick.

5. Thin alternation of dark-gray clayey silicites and cherty shales. Bed of dark silicite yielded radiolaries in the middle part of the unit. Thin $(<1 \mathrm{~mm})$ ash layers in the lower and upper parts of the unit. The unit is $5.8 \mathrm{~m}$ thick.

6. Lens-like layer of cherty detritic limestone grading to clayey limestone. $0.4 \mathrm{~m}$ thick.

7. Thin alternation of dark-gray clayey silicites and cherty shales interbedded by dark silicites in the lower part of the unit. Thin $(<1 \mathrm{~mm})$ ash layers in the uppermost part of the unit. $3 \mathrm{~m}$ thick.

Several lithological types compose the upper Tournaisian part of the Nyan-Vorga Fm. The most common lithological type is represented by thin alternation of dark-gray clayey silicites and cherty shales. The rocks of this lithological type contain more than $85 \%$ of $\mathrm{SiO}_{2}, 6-9 \%$ of $\mathrm{Al}_{2} \mathrm{O}_{3}, 1-1.5 \%$ of $\mathrm{K}_{2} \mathrm{O}, 0.6-1.5 \%$ of $\mathrm{Na}_{2} \mathrm{O}$, about $1 \%$ of $\mathrm{MgO}$ and $\mathrm{SO}_{3}$, and minor content of $\mathrm{CaO}, \mathrm{MnO}, \mathrm{TiO}_{2}, \mathrm{ZrO}_{2}, \mathrm{BaO}$, and $\mathrm{SrO}$ (according XRF data). The silicites with radiolaries and spicules, and black laminated shales occur as well. Rare carbonates are represented by clayey wavy laminated bio- and lithoclastic limestones and micritic clayey limestones, which form graded beds interpreted as calciturbidites. The silicites and shales are considered to be pelagic sediments. The limestones and shales are considered to be markers of regression, but silicites with radiolaries and spicules are interpreted as corresponding to transgression acme (Eremenko and Zhuravlev 2013).

The distribution of the lithological types in the section allows reconstructing sea level fluctuations. Four transgression-regression couplets can be recognized (Fig. 2). The first one comprises units 1 and 2; the second - units 2 and 3 , the third - units 4 and 5, and the forth - units 6 and 7.
Abundant sulphides and organic matter and sparse remains of benthos in the deposits suggest dysoxic bottom water conditions.

\section{Conodonts}

In spite of poor preservation the conodonts obtained from the samples studied allow recognizing a number of conodont zones (Fig. 2). Distribution of conodonts is shown in the text table 1 , and characteristic forms are figured in Figs. 3, 4. The lower part of the studied sequence (lower part of the Unit 1) contains Siphonodella lanei Zhuravlev et Plotitsyn, Polygnathus lidiae (Bardasheva et al.), Polygnathus distortus Branson et Mehl, Polygnathus inornatus Branson, Bispathodus stabilis (Branson et Mehl) Morphotype 2, and S-elements of Idioprioniodus. This conodont association is characteristic for the Siphonodella crenulata Zone. The overlaying barren interval (middle part of the Unit 1) is correlated with the Siphonodella isosticha Zone. The upper boundary of the zone is drawn by first appearance of Gnathodus typicus Cooper Morphotype 2, marking the base of the Gnathodus typicus Zone in the upper part of the Unit 1. Conodont associations of the Gnathodus typicus Zone (uppermost part of the Unit 1 through the lower part of the Unit 5) comprise Gnathodus punctatus (Cooper), Dollymae hassi Voges, Dollymae sp., Pseudopolygnathus oxypageus Lane et al. among others. Numerous prionoidinids (Kladognathus and Idioprioniodus) appear in the upper part of this zone. The first appearance of Scaliognathus anchoralis Branson et Mehl at the upper part of the Unit 5 marks base of the Scaliognathus anchoralis Zone. Conodonts of the zone are not divers and represented by the zonal index species in association with rare Gnathodus, Pseudopolygnathus oxypageus Lane et al., Kladognathus sp., and Idioprioniodus sp. (TextTable 1). 
Tab.1. Conodont distribution in the Nyan-Vorga section

\begin{tabular}{|c|c|c|c|c|c|c|c|c|c|c|c|c|c|c|c|}
\hline Zone & \multicolumn{2}{|c|}{ crenulata } & \multicolumn{8}{|c|}{ typicus } & \multicolumn{5}{|c|}{ anchoralis } \\
\hline Sample & 10 & $10-1$ & 11 & $11-1$ & $11-2$ & 13 & 15 & 16 & 18 & 19 & 21 & 22 & 23 & 26 & 27 \\
\hline B.stabilis $\mathrm{M} 2$ & $x$ & & & & & & & & & & & & & & \\
\hline S. lanei & $x$ & $x$ & & & & & & & & & & & & & \\
\hline P. lidiae & $x$ & & & & & & & & & & & & & & \\
\hline P. inornatus & $x$ & & & & $x$ & & & & & & & & & & \\
\hline P. distortus & & $x$ & & & & & & & & & & & & & \\
\hline P.communis & & & & & & & & $x$ & & & & & & & \\
\hline P. sp. & & & $x$ & & & & & & & & & & & & \\
\hline Ps.oxypageus & & & & & & & & $x$ & & & $x$ & & & & \\
\hline Protognathodus sp. & & & & & & & & $x$ & & & & & & & \\
\hline G. typicus M2 & & & $x$ & & & $x$ & & & & & & & & $x$ & \\
\hline G. punctatus & & & & & & $x$ & & & & & & & & & \\
\hline G. sp. & & & & $x$ & & & & $x$ & $x$ & $x$ & $x$ & & & & \\
\hline D. hassi & & & & & & & $x$ & $x$ & & & & & & & \\
\hline D. sp. & & & & & & & & $x$ & & & & & & & \\
\hline Sc. anchoralis & & & & & & & & & & & $x$ & $x$ & $x$ & & $x$ \\
\hline Kladognathus sp. & & & & & & & & & $x$ & & $x$ & & $x$ & & $x$ \\
\hline Idioprioniodus sp. & & $x$ & & & & & & $x$ & $x$ & & & & & & $x$ \\
\hline $\begin{array}{c}\text { Taxonomic } \\
\text { diversity }\end{array}$ & 4 & 2 & 2 & 1 & 1 & 2 & 1 & 7 & 3 & 1 & 4 & 1 & 2 & 1 & 3 \\
\hline $\begin{array}{c}\text { Abundance } \\
\left(\text { elements per } \mathrm{cm}^{3}\right)\end{array}$ & & & 17 & & & & & & 19 & & 27 & & & & \\
\hline
\end{tabular}

Generally 11 conodont species were found in the Gnathodus typicus Zone, and just 7 species in the Scaliognathus anchoralis Zone (Text-Table 1). The section under consideration demonstrates highest diversity of conodont associations in the Gnathodus typicus Zone in contrast to global conodont diversity with culmination in the Scaliognathus anchoralis Zone (Ziegler and Lane 1985).

Most of the conodont species distinguished in the section belong to "deep-water biofacies" according to Dreesen et al. (1986). Ubiquitous species, such as Polygnathus communis communis Branson et Mehl, Kladognathus sp., and Idioprioniodus sp., occur as well. These species probably dwelt upper part of the water column and spread over the different facies of the marine basin. The conodont associations of the upper part of the Gnathodus typicus Zone and the Scaliognathus anchoralis Zone are dominated by representatives of Prioniodinida (Scaliognathus, Dollymae, Kladognathus, and Idioprioniodus), ozarkodinids (Gnathodus, Pseudopolygnathus) are rare or absent.

\section{Ostracodes}

Two articulated ostracode shells of intermediate preservation were found in the clayey silicite of the basal part of Gnathodus typicus Zone (sample 11, upper part of the Unit 1).

The first shell on the basis of presence of caudal appendage and lateral spine can be attributed to the genus Sagittibythere Schornikov et Michailova, 1990 (family Bythocytheridae) firstly described from the upper Emsian of South Tian-Shan. The studied shell (Fig. 5A-E) differs from the type species of this genus in having strong convexity, massive lateral spine occupying central part of the valve, and straight the upper part of the front edge. Partly preserved shell is distinguishable on the CT scan. Its posterior-dorsal part is deformed, probably during diagenetic compaction. Just the dorsal and anterior-dorsal parts of the left valve are preserved. The right valve demonstrates better preservation, and it is possible to reconstruct the trapezoidal shape of the shells possessing broad lateral spine and a 
short dorsum (1/3 of shell length) (Fig. 5A, B). The spine angle in the horizontal plane is about $25^{\circ}$. Posterior cardinal angle is 160 , and anterior is 153 (Fig.5A). Median sulcus on the outer side of the valve is not expressed, but on the inner side the median transverse uplift can be distinguished (Fig. 5D). The free margin is slightly flattened and possesses keel form (Fig. $5 \mathrm{~B}, \mathrm{C})$.

The second ostracode shell (Fig. 5F-I) can be attributed to genus Tricornina (Bohemia). Valve outline is strongly preplete in lateral view, with straight dorsal margin, broadly rounded anterior margin, and truncated in ventroposterior part posterior margin forming a caudal process (Fig. 5F, G). The shell is strongly laterally flattened, with thin lateral spines in anterior-central region (Fig. 4F-I). The thin lateral spine is well distinguished on the left valve, where it is broken and bowed toward the shell. The spine on the right valve is broken near the base (Fig. 5G, H, I). The posterior margin of the shell bears deformed remains of caudal appendage (Fig. 5F-I). This specimen is similar to Tricornina (Bohemia) sp. described from the Lower Visean of the Montagne Noire (Lethiers and Feist 1991: pl. 2, fig. 6-7).

The shell morphology of both specimens suggests dwelling the quite-water soft-ground environment. It seems that Sagittibythere sp. and Tricornina (Bohemia) sp. were inhabitants of bathyal environment.

\section{Mid-Aikuanian Event}

The study stratigraphic interval comprises the Mid-Aikuanian global event, dated with conodonts as corresponding to Siphonodella isosticha and Gnathodus typicus zones (Saltzman et al. 2004; Yao et al. 2015). The Mid-Aikuanian Event is marked by significant positive shift in the carbon isotope ratio and prominent glacioeustatic regression (Saltzman et al. 2004; Yao et al. 2015).
The turnover in the conodont associations at this time, which led to extinction of siphonodellids and appearance and diversification of gnathodids (Lane and Ziegler 1987; Kalvoda 1994), probably was caused by the phase of Gondwana glaciation accompanied by glacioeustatic regression. The regression corresponding to the upper part of Unit 1 through the lower part of Unit 3 may be correlated with the Mid-Aikuanian global event. Last siphonodellids occur in the lowermost part of this interval, but first gnathodids appears in the middle part (Fig. 2, Text-Table 1). Appearance of the bathyal ostracodes is also reported in this interval (sample 11, upper part of the Unit 1).

\section{Conclusions}

Four transgression-regression couplets are reconstructed in the stratigraphic interval under consideration comprising the upper part of Siphonodella crenulata - Scaliognathus anchoralis zones (Fig. 2). Siphonodella crenulata Zone, barren interval correlated with Siphonodella isosticha Zone, Gnathodus typicus, and Scaliognathus anchoralis conodont zones have been identified. The conodont faunas provide the first biostratigraphically constrained correlations between bathyal deposits of the Lemva tectonic belt in the Polar Urals and the deeper-water "standard" conodont zonation. The regression located just above the base of the Gnathodus typicus Zone is correlated with the Mid-Aikuanian global event, which led to extinction of siphonodellids and appearance and diversification of gnathodids among conodonts.

The ostracodes Sagittibythere sp. and Tricornina (Bohemia) sp. are reported from the bathyal deposits Urals for a first time. Earlier ostracodes of the "Thuringian" ecotype in the Urals were found just in the facies of deep-water shelf depression and its slopes. 


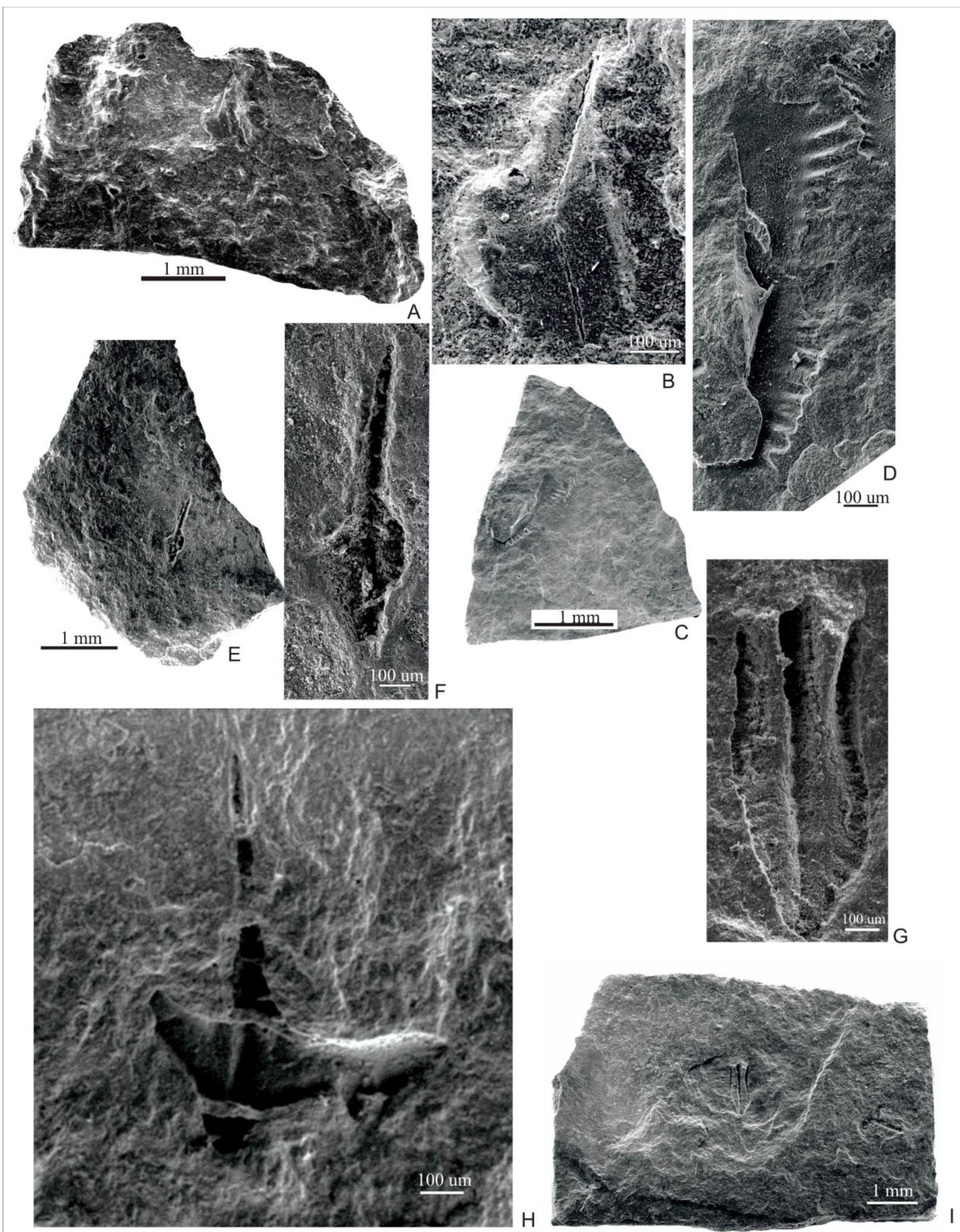

Fig.3. Conodont elements on the bedding planes from the Nyan-Vorga Formation. A, B - Siphonodella lanei Zhuravlev et Plototsyn, sample 10, specimen 45/687; C, D - Bispathodus stabilis (Branson et Mehl) Morphotype 2, sample 10, specimen 44/687; E, F - Gnathodus typicus Cooper Morphotype 2, sample 11, specimen 43/687; G, I - Polygnathus lidiae (Bardasheva, Bardashev, Weddige, Ziegler), sample 10-1, specimen 46/687; H Scaliognathus anchoralis Branson et Mehl, sample 27, specimen 47/687. 


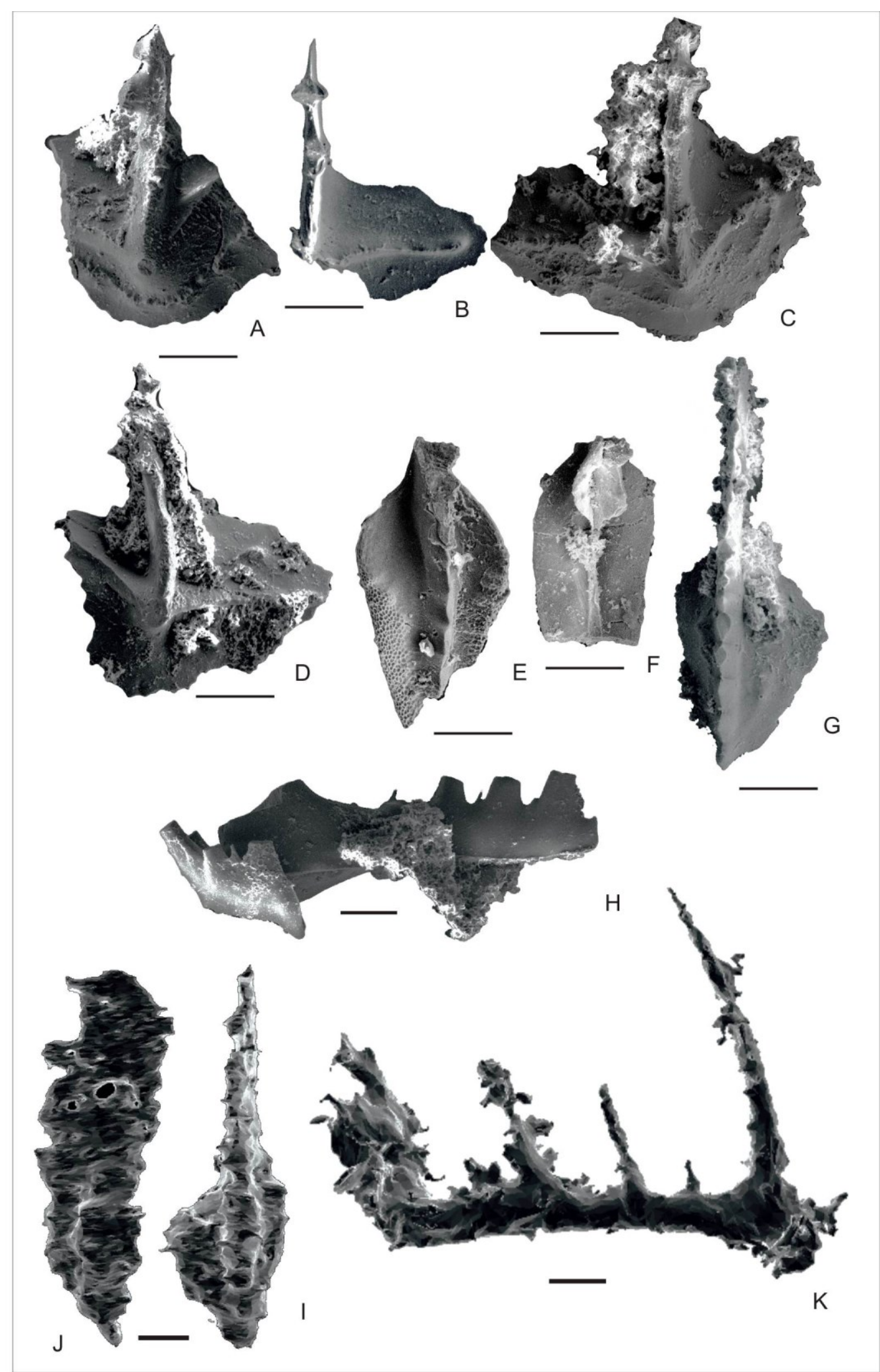

Fig.4. Conodont elements from the Nyan-Vorga Formation. A-D - Dollymae hassi Voges, sample 16, specimens 9/687, 15/687, 7/687, 8/687; E, F - Polygnathus communis communis Branson et Mehl, sample 16, specimens 10/687 and 11/687; G - Protognathodus praedelicatus Lane, Sandberg, Ziegler, sample 16, specimen 12/687; H - Idioprioniodus sp., sample 16, specimen 13/687; I, J - Gnathodus typicus Cooper Morphotype 2, sample 11, CT-scan, specimen 1/689; K - Kladognathus sp., sample 18, CT-scan, specimen 3/689. Scale bar $100 \mu \mathrm{m}$. 


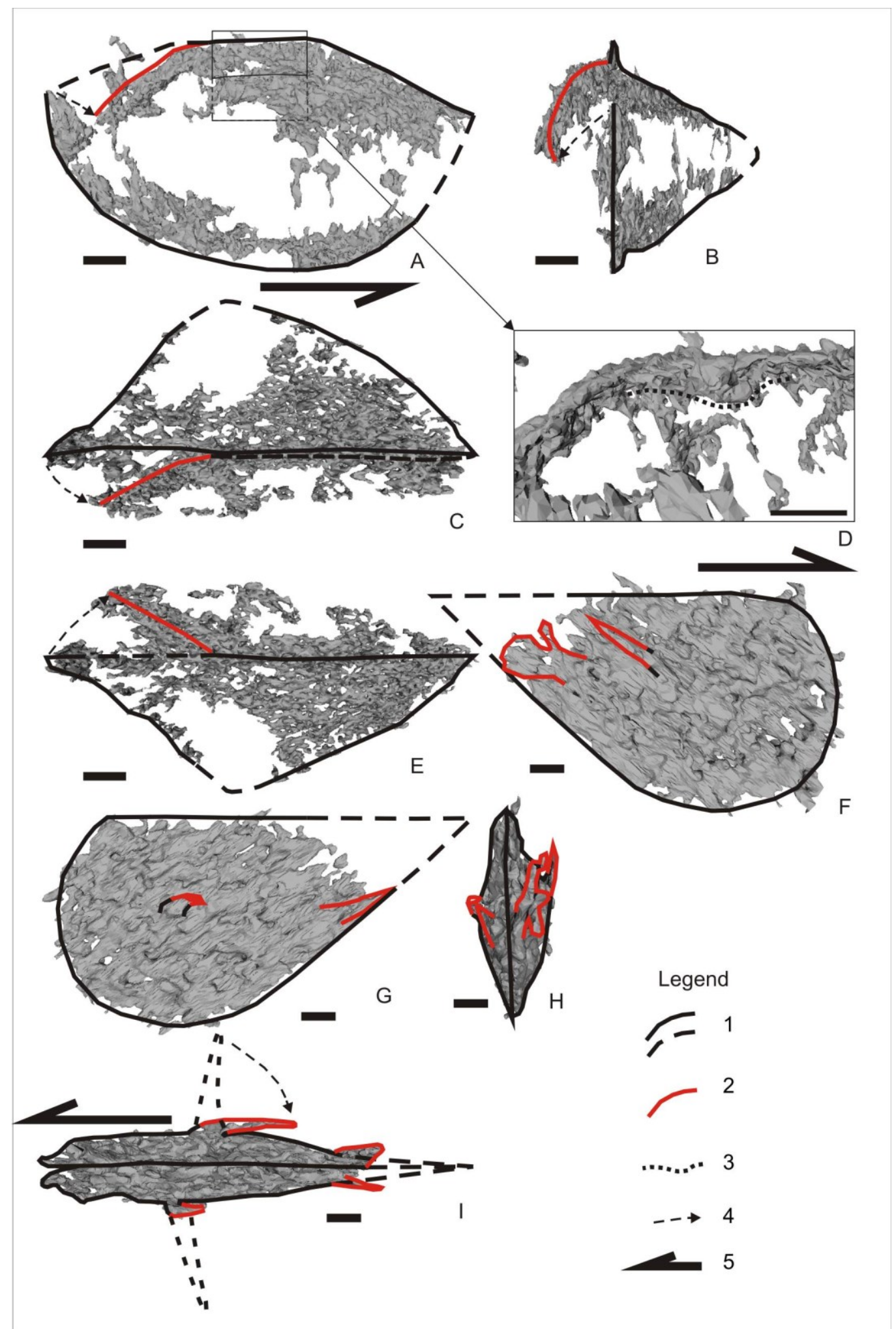

Fig.5. Ostracodes from the Nyan-Vorga Formation. A-E - Sagittibythere sp., sample 11, fragment of CT-scan of specimen 1/689: A - lateral view of the right valve; $\mathrm{B}$ - posterior view; $\mathrm{C}$ - ventral view; $\mathrm{D}$ - median transverse uplift on the inner side of the shell; E - dorsal view. F-I - Tricornina (Bohemia) sp., sample 11, fragment of CTscan of specimen 1/689: F - lateral view of the right valve; $\mathrm{G}$ - lateral view of the left valve; $\mathrm{H}$ - posterior view; I - dorsal view. Legend: 1 - outline of the shell and its reconstruction; 2 - deformed parts of the shell; 3 - median transverse uplift; 4 - supposed deformation direction; 5 - anterior-ward direction for the shell. Scale bar $100 \mu \mathrm{m}$. 


\section{Acknowledgements}

The authors are very grateful to Anastasiya Shtyrlaeva (Gornyi University, St. Petersburg, Russia) for help in tomographic study of the samples.

\section{References}

Bischoff G. (1957) Die ConodontenStratigraphie des rheno-herzynischen Unterkarbons mit Berücksichtigung der Wocklumeria-Stufe und der Devon/Karbon-Grenze. Abhandlungen des Hessischen Landesamtes fur Bodenforschung zu Weisbaden 19: 164.

Butler M. (1973) Lower Carboniferous conodont faunas from the Eastern Mendips, England. Palaeontology 16, 3: 477-517.

Dreesen R., Sadberg C.A., Ziegler W. (1986) Review of Late Devonian and Early Carboniferous conodont biostratigraphy and biofacies models as applied to the Ardenne shelf. Annales de la Societe geologique de Belgique 109: 27-42.

Eremenko N.M., Zhuravlev A.V. (2013) Lithological and genetic typization of the middle Palaeozoic deep-water deposits. Osadochnye basseyny, sedimentationnye i postsedimentationnye processy $\mathrm{V}$ geologicheskoy istorii. Materials of VII AllRussian lithological meeting (Novosibirsk, 28-31 Oct. 2013). Vol. I: 290-294.

Harris A.G. \& Sweet W.C. (1989) Mechanical and chemical techniques for separating microfossils from rock. Sediment and residue matrix. [In:] Paleotechniques (ed. R.M. Feldmann, R.E. Chapman \& J.T. Hannibal). Paleontol. Soc. Spec. Publ., 4: 70-86.

Ji Q. (1987) Early Carboniferous conodonts from Jianghua County of Hunan Province and their stratigraphic value - with a discussion on the Mid-Aikuanian Event. Bulletin of the Institute of Geology, Chinese
Academy of Geological Science. 16: 115141.

Kalvoda J. (1994) The conodont extinction at the Middle-Upper Tournaisian boundary. Geolines. 1: 12-15.

Lane H.R., Sandberg C.A., Ziegler W. (1980) Taxonomy and phylogeny of some Lower Carboniferous conodonts and preliminary standard post-Siphonodella zonation. Geologica et Palaeontologica. 14: 117-164.

Lethiers F., Feist R. (1991) Ostracodes, stratigraphie et bathymrtrie du passage Devonien-Carbonif'ere au Viseen inferieur en Montagne Noire (France). Geobios 24: 71- 104.

Puchkov V. (2002) Paleozoic evolution of the East European continental margin involved into the Urals. [In:] Mountain Building in the Uralides: Pangea to the Present (ed. D. Brown, C. Juhlin, V. Puchkov). AGU Geophysical Monograph Series, 132: 9-32.

Puchkov V.N. (2010) Geology of the Urals and Cis-Urals (actual problems of stratigraphy, tectonics, geodynamics and metallogeny). Design Poligraph Service, Ufa. 280 pp. [in Russian]

Saltzman M.R., Groessens E., Zhuravlev A.V. (2004) Carbon cycle models based on extreme changes in $813 \mathrm{C}$ : an example from the lower Mississippian. Paleogeography, Paleoclimatology, Paleoecology 213: 359377.

Sandberg C.A., Gutschick R.C. (1984) Distribution, microfacics and source rock potential of Mississippian Delle Phosphatic Member of Woodman Formation and equivalents, Utah and adjacent States. [In:] Hydrocarbon source rocks of the Greater Rocky Mountain region (ed. J. Woodward, F.F. Meissner \& J.L. Clayton). Denver, Colorado, Rocky Mountain Association of Geologists, 135-178.

Schornikov E. I., Michailova E. D. (1990) Ostracodes Bythocytheridae at early stage of development. Comparative morphology, 
paleoecology and evolutionary pathways. Nauka Publishers, Moscow. 278 pp. [in Russian]

Scotese C.R. (2016) PALEOMAP PaleoAtlas for GPlates and the PaleoDataPlotter program. Geological Society of America Abstracts with Programs 48, 5. DOI: 10.1130/abs/2016NC-275387

Thompson T.L., \& Fellows L.D. (1970) Stratigraphy and conodont biostratigraphy of Kinderhookian and Osagean (Lower Mississippian) rocks of southwestern Missouri and the adjacent area. Missouri Geological Survey - Report of Investigation 45: 1-263.

Tian S. \& Coen M. (2005) Conodont evolution and stratotype sign of carboniferous Tournaisian-Visean boundary in South China. Science in China Ser. D, Earth Sciences 48, 12: 2131-2141.

Varker W.J. \& Sevastopulo G.D. (1985) The Carboniferous System: Part. 1 - Conodonts of the Dinantian Subsystem from Great Britain and Ireland. [In:] A stratigraphical index of conodonts (ed. A.C. Higgins \& R.L. Austin). British Micropalaeontological Society Series, 167-209.

Yao L.; Qie W.; Luo G.; Liu J.; Algeo T. J.; Bai X.; Yang B. \& Wang X. (2015) The TICE event: Perturbation of carbon-nitrogen cycles during the mid-Tournaisian (Early Carboniferous) greenhouse-icehouse transition. Chemical Geology 401: $1-14$. DOI: 10.1016/j.chemgeo.2015.02.021

Yudin V.V. (1994) Orogenez Severa Urala i Pay-Khoya. Nauka Publishers, Ekaterinburg. 286 pp. [in Russian]

Zhuravlev A.V. (2003) Upper Devonian Lower Carboniferous conodonts of the north-east of European part of Russia. VSEGEI Publ., St. Petersburg. 85 pp. [in Russian]

Zhuravlev A.V., Gerasimova A.I. (2016a) Sequence composition and conodonts of the Kara Formation (Lower Carboniferous) of the Amderma Distirict of the Northern PayKhoy. Vestnik IG Komi SC UB RAS 1: 310. DOI: $10.19110 / 2221-1381-2016-1-3-10$ [in Russian]

Zhuravlev A.V., Gerasimova A.I. (2016b) XMT micropalaeontological study of the silicites. Vestnik IG Komi SC UB RAS 3: 26-32. DOI: 10.19110/2221-1381-2016-326-32

Ziegler W., Lane H.R. (1987) Cycles in conodont evolution from Devonian to midCarboniferous. [In:] Palaeobiology of conodonts (ed. R.J. Aldridge). 147-163. 